\title{
The Effect of Mixing Natural Aggregates with Artificial Aggregates on Marshall Parameters
}

\author{
Muhammad Riski ${ }^{1}$, Febrina Dian Kurniasari*1, Bunyamin ${ }^{1}$ \\ ${ }^{1}$ Universitas Iskandar Muda; Jl. Kampus Unida-Surien, telp. (0651) 42225 - 42098 - 42219 \\ Program Studi Teknik Sipil, Fakultas Teknik, Kota Banda Aceh \\ e-mail: ${ }^{1}$ riskijantho763@gmail.com, ${ }^{*}$ Ifebrina@unida-aceh.ac.id, ${ }^{1}$ bunyamin@unida-aceh.ac.id
}

ARTICLE INFO

Article history:

Accepted

Keywords:

Natural aggregate

Marshall parameters

Crushed stone

Optimum asphalt content

\section{ABSTRACT}

In general, aggregates consist of Natural Aggregates (NA) and Artificial Aggregates (AA). Artificial aggregates, such as Crushed Stone (CS), are aggregates produced through the crusher industry which has a rough and angular surface so that it has excellent adhesion to asphalt. Meanwhile, NA is an aggregate produced from a river which has a smooth and large hollow surface texture. The cost for AA is very expensive when compared to NA, so it is necessary to experiment with mixing NA and AA to minimize the use of AA. NA are obtained from Sungai Jalin, Jantho City District, Aceh Besar District. The method used refers to the specification of Bina Marga 2010 Revision four (2018) and the Indonesian National Standard (SNI). The purpose of this study was to see the effect of the combination of NA and AA as a substitute for coarse aggregate on the AC-WC concrete asphalt layer. The specimens used were 66 specimens with substitution of NA and AA into the asphalt layer were 0\% NA: $100 \%$ AA, $25 \%$ NA: $75 \%$ AA, $50 \%$ NA: $50 \%$ AA, $75 \%$ NA: $25 \%$ AA, $100 \%$ NA : $0 \%$ AA. Based on the research results, the best value for the optimum marshall parameter is the substitution of $25 \%$ AA: $75 \% \mathrm{BP}$ at asphalt content of $5.00 \%$, the stability value is $1492.37 \mathrm{~kg}$ with a VIM value of $3.69 \%$, VMA $16.17 \%$, VFA $77.88 \%$ and MQ $573.87 \mathrm{~kg} / \mathrm{mm}$ which have met the requirements of the 2010 Revision four (2018) Bina Marga specification.

Copyright (C) 2020 Politeknik Aceh Selatan. All rights reserved.

\section{Introduction}

Aggregates are grains of crushed stone, coarse aggregate, find aggregate or other minerals, both natural and artificial, in the form of large and small solid minerals [1]. Generally, the construction of asphalt concrete surface layers uses crushed stone as the aggregate. Crushed stone is obtained from rock excavated from mountain and river rocks which are crushed and sieved according to standard sizes [2]. However, the cost for artificial aggregates such as crushed stone is very expensive when compared to natural aggregates, so it is necessary to experiment with mixing natural and artificial aggregates to minimize the use of artificial aggregates.

Natural aggregates are aggregates that are round in shape and have a relatively slippery surface compared to artificial aggregates because these aggregates are eroded by water [3]. This aggregate also has poor adhesion to asphalt because it has a surface that tends to be smoother and slippery. Besides, the cavity generated by this aggregate is very large because it has a relatively round shape and does not have angles like artificial aggregate. Two forms of natural aggregate that are often used are coarse aggregate and fine aggregate. coarse aggregate is aggregate with size $>1 / 4$ inch $(6.35 \mathrm{~mm})$, fine aggregate is aggregate with vertical size [4].

Artificial aggregate is the aggregate produced through the stone crusher industry which has a rough and angular surface so that it has excellent adhesion to asphalt [5]. In addition, the cavities between the aggregates that occur are relatively smaller so that it can form good bonds between them. The use of artificial aggregates on road pavements is better then natural aggregates because 
the artificial aggregates have angles that can bind each other to the aggregates. However, what happens in the field requires a large budget for the use of crushed stone aggregate as a material in the mixture of asphalt concrete layers, and sometimes there are still natural agreements that meet the requirements that can be used as aggregate material on road pavements [6]. So it is necessary to do research by mixing natural aggregate with artificial aggregate on the parameters of marshall mixture of Asphalt Concrete -Wearing Course (AC - WC).

\section{Method}

the implementation of the research was to test the effect of mixing natural aggregates with artificial aggregates on marshall parameter at the Laboratory of Transportation, Engineering department, Iskandar Muda University, Banda Aceh. The method used is based on the fourth revision of the 2010 Highways Specification (2018) [7] and the Indonesian National Standard (SNI)[8].

The data used inthis research coasist of primary and secondary data. Primary data is the characteristics of each material to be used, such as natural and artificial aggregate characteristics, asphalt characteristics, and fillers. These data are obtained using material testing. Secondary data in this research such as a list of specifications, equipment calibration numbers and so on. Secondary data can be obtained from literature studies and related agencies

The artificial aggregate used was taken at the quarry location of PT Dana Dinamika Persada, which is located in Leupung Baleu, Kuta Cot Gilie District, Aceh Besar District. While the natural aggregate is taken from the Jalin River, Jantho City District, Aceh Besar.

The procedure of mixing natural aggregates with artificial aggregates on Marshall parameters are as follows.

\section{Preparation}

The preparations of this research consist of materials, and also the preparation of the equipment used. Material preparation before use and equipment checking carried out. The materials needed are 60/70 penetration asphalt, coarse aggregate, fine aggregate, natural aggregate and Portland cement type 2 [9]

\section{Testing materials}

Inspection of the material used follows the inspection procedure according to predetermined standards [10]:

a. testing of the physical properties of asphalt is penetration testing and inspection of the density of asphalt.

b. Examination of the physical properties of the aggregates which is carried out is the examination of density and absorption, weight of content and wear of the aggregate.

\section{Planning of asphalt concrete mix}

Calculate the initial estimate of the Central Asphalt Content $(\mathrm{Pb})$ using equation (1):

$$
P b=0,035(\% C A)+0,045(\% F A)+0,18(\% \text { Filler })+\mathrm{K}
$$

Where :

$\mathrm{Pb}$ : ideal asphalt content, percent of the weight of the mixture;

CA : percentage of aggregate held by sieve no.4 $(5 \mathrm{~mm})$;

FA : percentage of aggregate passes sieve no. $4(5 \mathrm{~mm})$ and held by sieve no.200 $(0.075 \mathrm{~mm})$;

Filler: Minimum aggregate percentage of $75 \%$ passes no. $200(0.075 \mathrm{~mm})$

$\mathrm{K}$ : Constant Value; 
The $\mathrm{Pb}$ value obtained from this study was $5 \%$ so that the AC-WC mixture test object was made at asphalt levels of $4, \%, 4.5 \%, 5 \%, 5.5 \%$, and $6 \%$ where each asphalt content was made. 3 specimens.

4. Making Test Objects

a. Test specimen with variations in asphalt content for determining the optimum asphalt content (OAC).

b. Test object with natural and artificial aggregate substitution of $0 \%$ NA: 100 AA, $25 \%$ NA: $75 \%$ AA, $50 \%$ NA: $50 \%$ AA, $75 \%$ NA: $25 \%$ AA and 100\% NA: $0 \%$ AA

c. Specimens with and without natural aggregate substitution produce the best Marshall characteristics for calculating the durability value. The number of specimens to determine the properties of the OAC determination mixture can be seen in Table 1 .

Table 1 Number of Test Objects for AC-WC OAC

\begin{tabular}{cccc}
\hline No & Asphalt Content & Object Code & Total \\
\hline 1 & $4,00 \%$ & A1,A2,A3 & 3 \\
2 & $4,50 \%$ & B1,B2,B3 & 3 \\
3 & $5,00 \%$ & C1,C2,C3 & 3 \\
4 & $5,50 \%$ & D1,D2,D3 & 3 \\
5 & $6,00 \%$ & E1,E2,E3 & 3 \\
\hline \multicolumn{5}{r}{ Total } & 15 \\
\hline
\end{tabular}

Marshall testing with variations in asphalt content of $4.00 \% ; 4,50 \% ; 5.00 \% ; 5.50 \%$; and $6.00 \%$, then analyzed to obtain the value of the Optimum Asphalt Content (OAC) which was obtained at $5.50 \%$ and the $\mathrm{OAC}$ value was varied into 3 asphalt levels of $5.00 \%, 5.50 \%$, and $6.00 \%$. For the number of specimens substitution of natural aggregate (NA) and artificial aggregate (AA) with 30 minutes immersion in Table 2.

Table 2. Number of NA and AA specimens

\begin{tabular}{|c|c|c|c|c|}
\hline No & Combination & Asphalt Content & Object Code & total \\
\hline 1 & $0 \% \mathrm{NA}: 100 \% \mathrm{AA}$ & $\begin{array}{c}\text { OAC }-0,5 \\
\text { OAC } \\
\text { OAC }+0,5\end{array}$ & $\begin{array}{l}\mathrm{A}_{11}, \mathrm{~A}_{12}, \mathrm{~A}_{13} \\
\mathrm{~A}_{21}, \mathrm{~A}_{22}, \mathrm{~A}_{23} \\
\mathrm{~A}_{31}, \mathrm{~A}_{32}, \mathrm{~A}_{33}\end{array}$ & 9 \\
\hline 2 & $25 \% \mathrm{NA}: 75 \% \mathrm{AA}$ & $\begin{array}{c}\text { OAC }-0,5 \\
\text { OAC } \\
\text { OAC }+0,5\end{array}$ & $\begin{array}{l}\mathrm{A}_{41}, \mathrm{~A}_{42}, \mathrm{~A}_{43} \\
\mathrm{~A}_{51}, \mathrm{~A}_{52}, \mathrm{~A}_{53} \\
\mathrm{~A}_{61}, \mathrm{~A}_{62}, \mathrm{~A}_{63}\end{array}$ & 9 \\
\hline 3 & $50 \% \mathrm{NA}: 50 \% \mathrm{AA}$ & $\begin{array}{c}\text { OAC }-0,5 \\
\text { OAC } \\
\text { OAC }+0,5\end{array}$ & $\begin{array}{l}\mathrm{A}_{71}, \mathrm{~A}_{72}, \mathrm{~A}_{73} \\
\mathrm{~A}_{81}, \mathrm{~A}_{82}, \mathrm{~A}_{83} \\
\mathrm{~A}_{91}, \mathrm{~A}_{92}, \mathrm{~A}_{93}\end{array}$ & 9 \\
\hline 4 & $75 \%$ NA : $25 \%$ AA & $\begin{array}{c}\text { OAC }-0,5 \\
\text { OAC } \\
\text { OAC }+0,5\end{array}$ & $\begin{array}{r}\mathrm{A}_{101}, \mathrm{~A}_{102}, \mathrm{~A}_{103} \\
\mathrm{~A}_{111}, \mathrm{~A}_{112}, \mathrm{~A}_{113} \\
\mathrm{~A}_{121}, \mathrm{~A}_{122,}, \mathrm{~A}_{123}\end{array}$ & 9 \\
\hline 5 & $100 \%$ NA : $0 \%$ AA & $\begin{array}{c}\text { OAC }-0,5 \\
\text { OAC } \\
\text { OAC }+0,5\end{array}$ & $\begin{array}{l}\mathrm{A}_{131}, \mathrm{~A}_{132}, \mathrm{~A}_{133} \\
\mathrm{~A}_{141}, \mathrm{~A}_{142,} \mathrm{~A}_{143} \\
\mathrm{~A}_{151}, \mathrm{~A}_{152}, \mathrm{~A}_{153}\end{array}$ & 9 \\
\hline \multicolumn{4}{|c|}{ Total } & 45 \\
\hline
\end{tabular}

After testing the combination of NA and AA, the best percentage value is obtained. Then the test object was made again to see the durability value for the 24 hour immersion as shown in table 3 


\begin{tabular}{ccc}
\hline No & Combination Experiments & Number of Test \\
\hline 1 & Best KAO mix & 3 \\
2 & AA Mix with Best BP & 3 \\
\hline \multicolumn{2}{r}{ Total } & 6 \\
\hline
\end{tabular}

\section{Results and Discussion}

Examination of the physical properties of aggregates and asphalt includes examining the abrasion of the aggregate by Los Angeles Machine; density, absorption of water and spefic gravity [11]. From the results of the examination, the physical properties of the aggregates have met the requirements. The results of the examination of the physical properties of artificial aggregates, natural aggregates, fine aggregates and 60/70 pen asphalt which meet all the specifications of Highways (2018) which are shown in Tables 4 to 7.

Table 4 Results of the Physical Properties of Artificial Aggregates

\begin{tabular}{|c|c|c|c|}
\hline Physical properties & Unit & Result & $\begin{array}{c}\text { Specification Bina } \\
\text { marga(2018) }\end{array}$ \\
\hline Specific gravity & - & 2,8 & Min. 2,5 \\
\hline Absorption & $\%$ & 0,495 & Maks. 3 \\
\hline Fill Weight & $\mathrm{kg} / \mathrm{cm}^{3}$ & 1,609 & Min. 1 \\
\hline Wear and tear (los angeles) & $\%$ & 21,52 & Maks. 40 \\
\hline
\end{tabular}

Table 5 Results of Physical Properties of Natural Aggregates

\begin{tabular}{|c|c|c|c|}
\hline Physical properties & Unit & Result & $\begin{array}{c}\text { Spesifikasi Bina } \\
\text { marga(2018) }\end{array}$ \\
\hline Specific gravity & - & 4,7545 & Min. 2,5 \\
\hline Absorption & $\%$ & 1,3305 & Maks. 3 \\
\hline Fill Weight & $\mathrm{Kg} / \mathrm{cm}^{3}$ & 1,494 & Min. 1 \\
\hline Wear and tear (los angeles) & $\%$ & 12,54 & Maks. 40 \\
\hline
\end{tabular}

Table 6 Results of the Physical Properties of Fine Aggregates

\begin{tabular}{cccc}
\hline Physical properties & Unit & Result & $\begin{array}{c}\text { Specification Bina } \\
\text { Marga (2018) }\end{array}$ \\
\hline Specific gravity & - & 2,80 & Min. 2,5 \\
Absorption & $\%$ & 0,70 & Maks. 3 \\
\hline Table 7 Results of Physical Properties of Asphalt Pen. 60/70 \\
\hline Physical properties & Unit & Result & $\begin{array}{c}\text { Specification Bina marga } \\
\text { (2018) }\end{array}$ \\
\hline Specific gravity & - & 1,020 & Min. 1 \\
Absorption & $(0,1$ & 64 & $60-70$ \\
\hline
\end{tabular}




\section{Marshall Test Results}

Based on the Marshall test results, namely VIM, VMA, VFA, stability, flow and Marshall Quotient (MQ) Marshall test results with variations in asphalt content of $4.0 \% ; 4.5 \% ; 5.0 \% ; 5.5 \%$ and $6.0 \%$, then an analysis was carried out to obtain the Optimum Asphalt Content (OAC) value which was obtained at $5.5 \%$. Then the OAC value was varied into three asphalt levels, namely $5.0 \% ; 5.5 \%$; and $6.0 \%$. The three levels of asphalt are used for testing the characteristics of the ACWC mixture of natural aggregate substitution (NA) with artificial aggregate (AA).

A recapitulation of the Marshall test results for the determination of the AC-WC mixture OAC is presented in Table 8:

Table 8 Recapitulation of Marshall Test Results with Variations in Asphalt Pen Levels. 60/70

\begin{tabular}{ccccccc}
\hline \multirow{2}{*}{$\begin{array}{c}\text { Mixed } \\
\text { Characteristics }\end{array}$} & \multicolumn{5}{c}{ Asphalt Content (\%) } & $\begin{array}{c}\text { Specification } \\
(2018)\end{array}$ \\
\cline { 2 - 6 } & 4,00 & 4,50 & 5,00 & 5,50 & 6,00 & $3-5$ \\
VIM (\%) & 10.71 & 7.63 & 3.61 & 3.47 & 3.24 & Min. 15 \\
VMA (\%) & 19.95 & 18.29 & 15.87 & 16.87 & 17.77 & Min. 65 \\
VFA (\%) & 46.76 & 58.44 & 77.63 & 79.55 & 81.93 & Min. 800 \\
Stabilitas (Kg) & 1363.81 & 1521.93 & 1531.90 & 1406.78 & 1402.43 & $2-4$ \\
Flow (mm) & 3.10 & 3.87 & 2.27 & 2.33 & 2.47 & Min. 250 \\
MQ (Kg/mm) & 451.53 & 406.29 & 757.93 & 626.44 & 588.59 & \\
\hline
\end{tabular}

Marshall test results for this phase were carried out on the three asphalt levels obtained from the determination of the $\mathrm{OAC}$ value, namely asphalt content of $5.00 \%, 5.50 \%$ and $6.00 \%$. A summary of the Marshall test results for aggregate variation can be seen in Tables 9 to 11 .

Table 9 Marshall Test Results with Natural Aggregate (NA) at Asphalt Levels 5.00\%

\begin{tabular}{lcccccc}
\hline & \multicolumn{7}{c}{ Natural Aggregate Variation (NA) - Artificial Aggregate (AA) (\%) } & \multicolumn{2}{c}{$\begin{array}{c}\text { Specification } \\
\text { Parameter }\end{array}$} & 0\%NA : & $25 \% \mathrm{NA}:$ & $50 \% \mathrm{NA}$ & $75 \% \mathrm{NA}:$ & $100 \% \mathrm{NA}:$ & Bina Marga \\
\cline { 2 - 5 } Marshall & $100 \% \mathrm{AA}$ & $75 \% \mathrm{AA}$ & $: 50 \% \mathrm{AA}$ & $25 \% \mathrm{AA}$ & $0 \% \mathrm{AA}$ & $(2018)$ \\
\hline VIM $(\%)$ & 3,61 & 3,69 & 3,96 & 4,30 & 4,65 & $3-5$ \\
VMA $(\%)$ & 15,87 & 16,17 & 16,65 & 17,19 & 17,76 & Min. 15 \\
VFA $(\%)$ & 77,63 & 77,88 & 76,49 & 75,04 & 73,83 & Min. 65 \\
Stability $(\mathrm{kg})$ & 1531,90 & 1492,37 & 1406,24 & 1387,20 & 1359,46 & Min. 800 \\
Flow $(\mathrm{mm})$ & 2,5 & 2,6 & 2,8 & 3,1 & 3,2 & $2-4$ \\
MQ $(\mathrm{kg} / \mathrm{mm})$ & 634,95 & 573,87 & 496,40 & 447,55 & 423,40 & Min. 250 \\
\hline
\end{tabular}

Table 10 Marshall Test Results with Natural Aggregate (NA) at Asphalt Levels of 5.50\%

\begin{tabular}{ccccccc}
\hline & \multicolumn{3}{c}{ Natural Aggregate Variation (NA) - Artificial Aggregate (AA) (\%) } & \multicolumn{2}{c}{ Specification } \\
Parameter & $0 \% \mathrm{NA}:$ & $25 \% \mathrm{NA}:$ & $50 \% \mathrm{NA}$ & $75 \% \mathrm{NA}:$ & $100 \% \mathrm{NA}$ & Bina Marga \\
\cline { 2 - 5 } Marshall & $100 \% \mathrm{AA}$ & $75 \% \mathrm{AA}$ & $: 50 \% \mathrm{AA}$ & $25 \% \mathrm{AA}$ & $: 0 \% \mathrm{AA}$ & $(2018)$ \\
\cline { 2 - 5 } & 3,47 & 3,55 & 3,78 & 3,90 & 4,26 & $3-5$ \\
\hline
\end{tabular}




\begin{tabular}{ccccccc}
\hline VMA $(\%)$ & 16,87 & 17,19 & 17,69 & 18,02 & 18,60 & Min. 15 \\
VFA $(\%)$ & 79,55 & 79,39 & 78,62 & 78,85 & 77,10 & Min. 65 \\
Stability $(\mathrm{kg})$ & 1406,78 & 1402,61 & 1382,67 & 1364,53 & 1331,71 & Min. 800 \\
Flow $(\mathrm{mm})$ & 2,6 & 2,7 & 3,0 & 3,3 & 3,5 & $2-4$ \\
$M Q(\mathrm{~kg} / \mathrm{mm})$ & 533,54 & 520,25 & 456,01 & 425,30 & 384,73 & Min. 250 \\
\hline
\end{tabular}

Table 11 Marshall Test Results with Natural Aggregate (NA) at Asphalt Levels 6.00\%

\begin{tabular}{ccccccc}
\hline & \multicolumn{5}{c}{ Natural Aggregate Variation (NA)-Artificial Aggregate (AA) (\%) } & Specification \\
\cline { 2 - 6 } Parameter & $0 \% \mathrm{NA}:$ & $25 \% \mathrm{NA}:$ & $50 \% \mathrm{NA}$ & $75 \% \mathrm{NA}:$ & $100 \% \mathrm{NA}: 0$ & Bina Marga \\
Marshall & $100 \% \mathrm{AA}$ & $75 \% \mathrm{AA}$ & $: 50 \% \mathrm{AA}$ & $25 \% \mathrm{AA}$ & $\% \mathrm{AA}$ & $(2018)$ \\
\hline VIM $(\%)$ & 3,24 & 3,32 & 3,49 & 3,61 & 4,03 & $3-5$ \\
VMA $(\%)$ & 17,77 & 18,11 & 18,53 & 18,92 & 19,58 & Min. 15 \\
VFA $(\%)$ & 81,93 & 81,71 & 81,19 & 80,94 & 79,47 & Min. 65 \\
Stability $(\mathrm{kg})$ & 1402,43 & 1381,03 & 1360,00 & 1316,48 & 1279,49 & Min. 800 \\
Flow $(\mathrm{mm})$ & 2,7 & 2,9 & 33 & 3,6 & 3,8 & $2-4$ \\
MQ $(\mathrm{kg} / \mathrm{mm})$ & 524,75 & 476,86 & 417,43 & 366,86 & 340,06 & Min. 250 \\
\hline
\end{tabular}

\section{Discussion of Marshall Test Results}

a. Discussion of VIM (void in the mix)

The results showed that with the addition of the variation in the percentage of natural aggregates, the VIM value increased but decreased as the bitumen content increased. This shows that the asphalt content greatly affects the cavities in the mixture or the VIM value. The higher the value of the asphalt content added to the mixture, the less the volume of the cavity in the mixture or the smaller the VIM value. The increase in VIM value is due to the large cavity caused by natural aggregates which tend to be round. The VIM value has met the specifics of Highways (2018), namely $3 \%-5 \%$ can be seen in table 12 .

Table 12 VIM Value of AA-BP Aggregate Variation with Variation in Asphalt Levels

\begin{tabular}{cccc}
\hline \multirow{2}{*}{$\mathrm{NA}+\mathrm{AA}$} & \multicolumn{3}{c}{ Asphalt Content (\%) } \\
\cline { 2 - 4 } & $5,00 \%$ & $5,50 \%$ & $6,00 \%$ \\
\hline $0 \% \mathrm{NA}: 100 \% \mathrm{AA}$ & 3,61 & 3,47 & 3,24 \\
$25 \% \mathrm{NA}:$ : 75\% AA & 3,69 & 3,55 & 3,32 \\
$50 \% \mathrm{NA}: 50 \% \mathrm{AA}$ & 3,96 & 3,78 & 3,49 \\
$75 \% \mathrm{NA}:$ : 75\% AA & 4,30 & 3,90 & 3,61 \\
$100 \% \mathrm{NA}: 0 \% \mathrm{AA}$ & 4,65 & 4,26 & 4,03 \\
\hline
\end{tabular}

b. Discussion of VMA (Void in Mineral Agregat)

The results showed that the increasing composition of natural aggregates in the asphalt mixture tended to increase. This was because the VMA value was influenced by natural aggregates which had a slippery shape so that they could not provide strong bonds between them. The lowest 
VMA value was 15.87 at the composition of $0 \%$ NA: $100 \%$ AA at $5.00 \%$ asphalt content, while the highest VMA value was $19.58 \%$ at the composition of $100 \%$ NA: $0 \%$ AA at $6.00 \%$ asphalt content. The VMA value indicates that it has met all of the specifics of Highways (2018), namely $\geq 15 \%$ can be seen in table 13 .

Table 13 VMA Value of NA-AA Aggregate with Variation of Asphalt Levels

\begin{tabular}{cccc}
\hline \multirow{2}{*}{$\mathrm{NA}+\mathrm{AA}$} & \multicolumn{3}{c}{ Asphalt Content (\%) } \\
\cline { 2 - 4 } & $5,00 \%$ & $5,50 \%$ & $6,00 \%$ \\
\hline $0 \% \mathrm{NA}: 100 \% \mathrm{AA}$ & 15,87 & 16,87 & 17,77 \\
$25 \% \mathrm{NA}: 75 \% \mathrm{AA}$ & 16,17 & 17,19 & 18,11 \\
$50 \% \mathrm{NA}: 50 \% \mathrm{AA}$ & 16,65 & 17,64 & 18,53 \\
$75 \% \mathrm{NA}: 75 \% \mathrm{AA}$ & 17,19 & 18,02 & 18,92 \\
$100 \% \mathrm{NA}: 0 \% \mathrm{AA}$ & 17,76 & 18,60 & 19,58 \\
\hline
\end{tabular}

\section{c. Discussion of VFA}

The results showed that the VFA value decreased along with the increase in the composition of the natural aggregate in the asphalt mixture because the natural aggregate had large pores so that the asphalt would be absorbed by the natural aggregate which resulted in a reduction in the asphalt blanket between the aggregates. The highest VFA value was at asphalt content of $6.00 \%$ at the composition of $0 \%$ NA: $100 \%$ AA at $81.93 \%$, while the lowest VFA value was at asphalt content at $5.00 \%$ at the composition of $100 \%$ NA: $0 \%$ AA of $73.83 \%$. The VFA value has met all of the specifics of Highways (2018), namely $\geq 65 \%$ can be seen in table 14 .

Table 14 VFA Value of NA-AA Aggregate Variation with Variation of Asphalt Levels

\begin{tabular}{cccc}
\hline NA + AA & \multicolumn{3}{c}{ Asphalt Content (\%) } \\
\cline { 2 - 4 } & $5,00 \%$ & $5,50 \%$ & $6,00 \%$ \\
\hline 0\% NA : 100\% AA & 77,53 & 79,55 & 81,93 \\
$25 \%$ NA : 75\% AA & 77,88 & 79,39 & 81,71 \\
$50 \%$ NA : 50\% AA & 76,49 & 78,62 & 81,19 \\
$75 \%$ NA : 75\% AA & 75,04 & 78,85 & 80,94 \\
$100 \%$ NA : 0\% AA & 73,83 & 77,10 & 79,47 \\
\hline
\end{tabular}

\section{d. Discussion of Stability}

The results showed that the increasing composition of natural aggregate (NA) in the asphalt mixture tended to decrease. This was due to the fact that natural aggregate was not able to provide strong binding power between particles in the mixture so that the stability decreased. The stability value is influenced by internal friction, inter-looking interlocking and good binding capacity of the asphalt layer (cohesion), besides the compaction process, aggregate quality, and asphalt content are also influential[12]. The value of stability with the increase in the composition of natural aggregates has met the requirements of Highways (2018), which is $\geq 800 \mathrm{~kg}$ can be seen in Figure 1. 


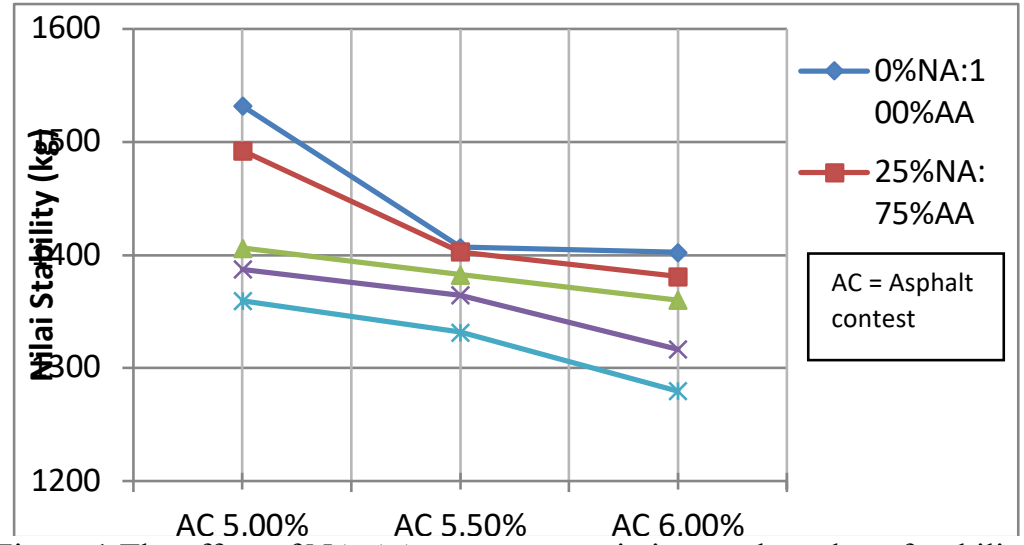

Figure 1 The effect of NA-AA aggregate variation on the value of stability

e. Discussion of Flow

The results showed that the flow value increased along with the increase in the composition of natural aggregates into the mixture. The high flow value characterizes the plastic mixture due to the high bitumen content. Meanwhile, if the flow value is very low, it will give the characteristic of a stiff mixture due to the low bitumen content [13]. The highest flow value was at asphalt content of $6.00 \%$ at the composition of $100 \%$ AA: $0 \%$ BP, namely $3.8 \mathrm{~mm}$ and the lowest value at asphalt content was $5.00 \%$ at the composition of $0 \% \mathrm{NA}: 100 \%$ AA, namely $2.5 \mathrm{~mm}$. The flow value in table 4.13 shows that it has met all the specifics of Highways (2018), namely $2-4 \mathrm{~mm}$ can be seen in table 15

Table 15 Value of flow of NA-AA aggregate with variation of asphalt levels.

\begin{tabular}{cccc}
\hline NA + AA & \multicolumn{3}{c}{ AC (\%) } \\
\cline { 2 - 4 } & $5,00 \%$ & $5,50 \%$ & $6,00 \%$ \\
\hline 0\% NA : 100\% AA & 2,5 & 2,6 & 2,7 \\
$25 \%$ NA : 75\% AA & 2,6 & 2,7 & 2,9 \\
$50 \%$ NA : 50\% AA & 2,8 & 3,0 & 3,3 \\
$75 \%$ NA : 75\% AA & 3,1 & 3,3 & 3,6 \\
100\% NA : 0\% AA & 3,2 & 3,5 & 3,8 \\
\hline
\end{tabular}

\section{f. Mashall Quotient (MQ)}

The results showed that the Masrhall Quotient (MQ) value decreased along with the increase in asphalt content and natural aggregate composition into the mixture. The smaller the MQ value, the more flexible the mixture is [14]. The highest Masrhall Quotient (MQ) value was at asphalt content of $5.00 \%$ at the composition of $0 \% \mathrm{AA}: 100 \% \mathrm{BP}$, namely $635.0 \mathrm{~kg} / \mathrm{mm}$ and the lowest value was at asphalt content of $6.00 \%$ at the composition of $100 \%$ AA: $0 \%$ BP, namely $340.1 \mathrm{~kg} / \mathrm{mm}$. The MQ value in table 4.14 shows that it has met all of the specifics of Highways (2018), namely $\geq 250 \mathrm{~kg} / \mathrm{mm}$ can be seen in table 16 . 
Table 16 MQ Value of NA-AA Aggregate Variation with Variation of Asphalt Levels

\begin{tabular}{cccc}
\hline NA + AA & \multicolumn{3}{c}{ AC (\%) } \\
\cline { 2 - 4 } & $5,00 \%$ & $5,50 \%$ & $6,00 \%$ \\
\hline 0\% NA : 100\% AA & 635,0 & 553,5 & 524,8 \\
25\% NA : 75\% AA & 573,9 & 520,3 & 476,9 \\
50\% NA : 50\% AA & 496,6 & 456,0 & 417,4 \\
$75 \%$ NA : 75\% AA & 447,5 & 425,3 & 366,9 \\
100\% NA : 0\% AA & 423,4 & 384,7 & 340,1 \\
\hline
\end{tabular}

\section{Durability Value Calculation Results}

The value of durability was obtained from the comparison between the stability of the immersion for 24 hours and the stability of the immersion for 30 minutes at $60{ }^{\circ} \mathrm{C}$. The results of calculating the durability value for each asphalt mixture composition can be seen in Table 17

Table 17 Results of Durability Testing Recapitulation

\begin{tabular}{cccc}
\hline \multicolumn{1}{c}{ Mixed Composition Type } & $\begin{array}{c}\text { Soaking } 30 \\
\text { minutes }\end{array}$ & $\begin{array}{c}24 \text { hour } \\
\text { soaking }\end{array}$ & $\begin{array}{c}\text { Durability Value } \\
\text { (\%) }\end{array}$ \\
\hline B & c & d & $\mathrm{e}=(\mathrm{d} / \mathrm{c}) \times 100$ \\
\hline $\begin{array}{l}\text { No substitution (standard) } \\
\begin{array}{l}\text { Mix with natural aggregate and } \\
\text { crushed stone aggregate }\end{array}\end{array}$ & 1531,90 & 1510,14 & 98.58 \\
\hline
\end{tabular}

The durability values for the mixture without substitution and with the substitution of natural aggregates were $98.58 \%$ and $96.88 \%$, respectively. From the results of the study, it can be seen that there is a decrease in the value of stability in the mixture with the substitution of natural aggregates, but the durability value still meets the requirements set by the Bina Marga Specifications 2010 revision 4 of 2018 [7] namely> 90\%. The decrease in the durability value in the AC-WC mixture was due to the large VIM, VMA values and small VFA values. This means that the AC-WC mixture with natural aggregate substitution has bigger cavities so that water easily enters the pores of the mixture which results in reduced adhesion and cohesion properties. The large cavity in the mixture causes a lot of air in the asphalt concrete, making it easier for the asphalt blanket to oxidize with air, becoming brittle, causing its durability to decrease [15].

\section{Conclusion}

The results of the examination of the physical properties of the material in the form of aggregate and asphalt pen 60/70 have met the required specifications and can be used as an ACWC mixture. Based on the evaluation of Marshall parameters, the minimum asphalt content is 5.00, the middle asphalt content is $5.50 \%$ and the maximum asphalt content is $6.00 \%$.

Based on the results of the evaluation of Marshall characteristics in the AC-WC mixture, the best composition for the combination using artificial aggregate (AA) and natural aggregate (NA) was obtained at a composition of $25 \% \mathrm{NA}-75 \%$ AA at $5.00 \%$ asphalt content, the stability value is $1492,37 \mathrm{~kg}$, meets specifications and can be used as an aggregate in the laston AC-WC mixture. 
Substitution of natural aggregates with artificial aggregates can affect the value of the Marshall test parameters which include VIM, VMA, VFA, Stability, and Flow. This effect is in the form of decreased stability.

\section{Acknowledgment}

The author is grateful for the support provided by the supervisor in conducting this research and the writer also thanks friends who helped the author in conducting this research.

\section{References}

[1] S. Sukarman, Beton Aspal Campuran Panas. Yayasan Obor Indonesia, 2003.

[2] I. R. B. Putri, H. Hariyadi, I. D. M. A. Karyawan, and E. Ahyudanari, "Pengaruh Variasi Penambahan Agregat Buatan Terhadap Kadar Aspal Optimum untuk Perkerasan Aspal Lapis Aus," J. Tek. ITS, vol. 7, no. 2, pp. E104--E113, 2019.

[3] B. Bulgis, R. B. Alkam, and others, "Pemanfaatan Agregat Alami dan Agregat Batu Pecah Sebagai Material Perkerasan Pada Campuran Aspal Beton,” Potensi J. Sipil Politek., vol. 19, no. $1,2017$.

[4] G. Tarigan, "PENGARUH PENGGUNAAN AGREGAT ALAM PADA CAMPURAN ASPAL BETON TERHADAP MARSHALL PROPERTIES," in Seminar Nasional Teknik (SEMNASTEK) UISU, 2019, vol. 2, no. 1, pp. 170-173.

[5] M. Al Mahbubi, "Studi Penggunaan Agregat Buatan Berbahan Dasar Fly Ash Pada Agregat Kasar Terhadap Perkerasan Lentur Untuk Pengurangan Penggunaan Agregat Alam," Institut Teknologi Sepuluh Nopember, 2019.

[6] R. Syahputra, "PENGARUH AGREGAT BERBENTUK BULAT (ROUNDED AGGREGATE) TERHADAP KARAKTERISTIK MARSHALL CAMPURAN BETON ASPAL AC-WC MENGGUNAKAN ASPAL PENETRASI 60/70 SEBAGAI BAHAN PENGIKAT," ETD Unsyiah, 2013.

[7] B. Marga, "Spesifikasi Umum (2018)," Direktorat Jendral Bina Marga. Dep. Pekerj. Umum, 2010.

[8] S. N. I. Revisi, “SNI 03-1737-1989, 2006,” Pelaks. Lapis Campuran beraspal Panas, Dep. Pekerj. Umum.

[9] A. Gunarto and A. I. Candra, "Penelitian Campuran Aspal Beton Dengan Menggunakan Filler Bunga Pinus," UKaRsT, vol. 3, no. 1, pp. 37-47, 2019.

[10] F. D. Kurniasari, S. M. Saleh, and S. Sugiarto, "PENGARUH FILLER ABU AMPAS TEBU (AAT) DENGAN BAHAN PENGIKAT ASPAL PEN 60/70 PADA CAMPURAN LASTON AC-WC," J. Arsip Rekayasa Sipil dan Perenc., vol. 1, no. 4, pp. 69-78, 2018.

[11] R. M. YUSPUTRI, "PENGARUH PENGGUNAAN ABU SERBUK KAYU SEBAGAI SUBSTITUSI FILLER DAN STYROFOAM SEBAGAI SUBSTITUSI AC PEN. 60/70 TERHADAP CAMPURAN LASTON-WC," ETD Unsyiah, 2019.

[12] M. S. Nugroho, "KARAKTERISTIK MARSHALL QUOTIENT PADA HOT MIX ASPHALT MENGGUNAKAN AGREGAT ALAM SUNGAI OPAK," Inf. dan Ekspose Has. Ris. Tek. SIpil dan Arsit., vol. 15, no. 2, pp. 84-91, 2019.

[13] G. S. Muaya, O. H. Kaseke, and M. R. E. Manoppo, "Pengaruh Terendamnya Perkerasan Aspal oleh Air Laut yang Ditinjau terhadap Karakteristik Marshall,” J. Sipil Statik, vol. 3, no. 8, 2015.

[14] M. Misbah, "PENGARUH VARIASI KADAR AGREGAT HALUS TERHADAP NILAI KARAKTERISTIK CAMPURAN PANAS ASPAL AGREGAT (AC-WC) DENGAN PENGUJIAN MARSHALL," J. Momentum, vol. 15, no. 2, 2013.

[15] A. Fahmi, S. M. Saleh, and M. Isya, "PENGARUH PENGGUNAAN AGREGAT HALUS JAMUR UJUNG PADA CAMPURAN LASTON AC-WC," J. Arsip Rekayasa Sipil dan Perenc., vol. 2, no. 1, pp. 1-10, 2019. 